\title{
The Next American Dream
}

At the end of The Machine in the Garden, his classic account of the pastoral ideal as expressed in American literature, Leo Marx notes that "American writers seldom, if ever, have designed satisfactory endings for their pastoral fables."

What Marx has in mind is exemplified by the conclusions of canonic novels such as Huckleberry Finn, in which Huck declares his intention to "light out for the Territory" in order to extend the experience of communion with Jim on the raft; or The Great Gatsby, with Nick Carraway retreating to a Midwest that has "all but disappeared;" or even the non-fictional Walden, in which Thoreau leaves the woods to return to Concord, explaining, ambiguously, that "I left the woods for as good a reason as I went there. Perhaps..."

These unsatisfactory resolutions, Marx suggests, reveal that "our inherited symbols of order and meaning have been divested of meaning," compelling us "to recognize that the aspirations once represented by the symbol of an ideal landscape have not, and probably cannot be, embodied in our traditional institutions." This means, he continues, "that an inspiriting vision of a human community has been reduced to a token of individual survival."

"To change the situation," he concludes, "we require new symbols of possibility..."

Little, it seems, has changed during the 36 years since The Machine in the Garden was first published in 1964. In The Real American Dream, a slim book based on a series of lectures given at Harvard University in 1998, Andrew Delbanco, a professor of humanities at Columbia University, offers what he calls a "meditation on hope" based on his reflections on the changing ideas of value and transcendence that have dominated the American imagination since early colonial times.

Despite his upbeat subtitle, however, the story Delbanco has to tell is hardly encouraging. Hope, Delbanco suggests, depends onwe might even say is the product of - a story that has a real hold on our imagination and that offers an end or purpose to life that transcends "our own tiny allotment of days and hours." But his account of the stories our culture has provided to provide access to transcendence is itself a tale of decline-actually of the diminution of hope toward what he calls "the vanishing point of the self alone."

At first, he suggests, the Puritan divines offered transcendence through grace, regarded as a gift from God. The old Puritan faith gradually lost its hold on the American imagination, however, and as it faded from view during the first half of the 19th century, it was replaced by a new faith in the nation and its experiment in democratic government proclaimed by figures such as Emerson, Whitman, and Lincoln.

This faith, he suggests, lost its hold on the American imagination between the 1960s and the 1980s, a victim of the disillusion that resulted from a succession of federally sponsored tragedies that began with the war in Vietnam. What replaced it, he suggests, was a culture of the self in which the essence of the good life is the experience of pleasure unmixed with the guilt or shame that, though painful, is the key to hope precisely because it reassures us that "there is something in the world that transcends (the self)," and makes ultimate demands on it.

All this is a familiar story, in many ways. Reading Delbanco's account, however, it occurred to me that he has left something out. It may be true that American-even Western-cultures have, broadly speaking, moved closer to the total collapse into the individual self that Emerson himself prefigured in his doctrine of radical self-reliance. But it is also true that the interest in the environment and the concern for its well-being that has emerged, not only in the West but also in other parts of the world, during the very period when Delbanco sees little but a turning inward to personal pleasures may be seen as a significant-and certainly hopeful-step in the opposite direction. Certainly, at least to the extent that this reflects more than a selfish concern for our own well being and survival, this development reflects a movement of the self outward toward an engagement with and a sense of oblig. ation toward beings other than ourselves.

Of course, as Leo Marx reminds us, a mere turning to nature hardly solves the problem of human loneliness and alienation. That, he suggests, is one thing we have to learn from the unsatisfactory outcomes of the stories of Huck Finn, Jay Gatsby and Henry Thoreau. But if, as Marx suggests, the old symbols of possibility are obsolete, there is always the possibility of inventing new symbols of possibility - and this, I believe, is where we may find a crucial role for restoration.

If the pastoral experiment no longer succeeds, in part because the green world of nature has been too severely compromised-because, as Marx once said, Huck's "Territory" is now Kansas City - it also fails in part because of the radical individualism that has marked it since the time of Emerson and Thoreau.

Restoration is important here because it provides a new way of carrying out the pastoral experiment that solves both problems. To begin with, it is a way of expanding and improving rather than gradually consuming the classic landscapes that provided the key symbol of possibility for the old pastoral. At the same time it lends itself to communal, rather than purely personal action. And beyond that, by dramatizing radical dependencenot only of us on nature, but of the natural landscape on our deliberate effort-it decisively puts an end to the old, alienating notion that either can be self-sufficient in any serious way.

If in the end the key to salvation lies not in the self but in service to others, as Delbanco suggests, this may be the key to a new paradigm of transcendence.

William R. Jordan III 